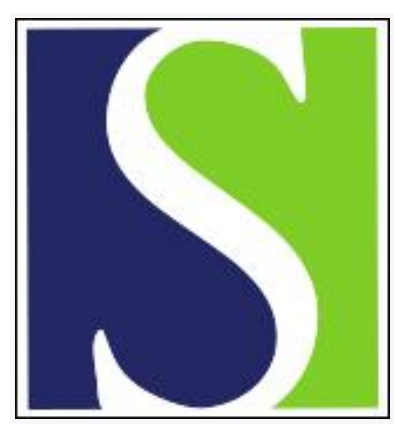

Scand J Work Environ Health 2003;29(1):71-77

https://doi.org/10.5271/sjweh.707

Issue date: Feb 2003

Prolonged respiratory symptoms caused by thermal degradation products of freons

by Piirilä P, Espo T, Pfäffli P, Riihimäki V, Wolff H, Nordman H

Affiliation: Helsinki University Hospital, Laboratory of Clinical Physiology, PO Box 360, 00290 HUS, Finland. paivi.piirila@hus.fi

Refers to the following text of the Journal: 1996;22(3):191-196

Key terms: bronchiolitis obliterans; case study; chlorofluorocarbons; freon; occupational irritant-induced asthma; reactive airways dysfunction syndrome; respiratory symptom; thermal degradation product

This article in PubMed: www.ncbi.nlm.nih.gov/pubmed/12630439

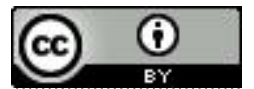




\title{
Prolonged respiratory symptoms caused by thermal degradation products of freons
}

\author{
by Päivi Piirilä, MD, ${ }^{1,2}$ Timo Espo, MD, ${ }^{1}$ Pirkko Pfäffli, MSc, ${ }^{3}$ Vesa Riihimäki, MD, ${ }^{3}$ Henrik Wolff, MD, ${ }^{1}$ \\ Henrik Nordman, $M D^{1}$
} Piirilä P, Espo T, Pfäffli P, Riihimäki V, Wolff H, Nordman H. Prolonged respiratory symptoms caused by thermal
degradation products of freons. Scand J Work Environ Health 2003;29(1):71-77.

\begin{abstract}
Objectives The chlorofluorocarbons (CFC) used in refrigeration systems decompose on heating and produce substances that are highly irritating to the airways (eg, chlorine, carbonyl fluoride, and hydrogen fluoride). This study examined persistent respiratory symptoms among several workers exposed to thermal decomposition products of CFC.

Methods Seven patients with respiratory symptoms caused by inadvertent exposure to thermal decomposition products of CFC in a restaurant kitchen or during refrigerator repair were studied with the use of spirometry, peak flow follow-up, and histamine challenge tests. Three patients also underwent bronchoscopy and bronchoalveolar lavage.

Results In five of the cases, cough or dyspnea lasted longer than 1 month; for three of the five, the symptoms lasted more than 4 years. Three cases showed increased bronchial hyperreactivity, and two of the three had increased diurnal peak flow variation. Three patients fulfilled the criteria for acute irritant-induced asthma or reactive airway dysfunction syndrome. One case exhibited bronchiolitis while, for the other six, the clinical picture was consistent with bronchitis.
\end{abstract}

Conclusions The studied cases indicate that the thermal decomposition products of CFC used in refrigerators may cause irritant-induced airway diseases of long duration.

Key terms bronchiolitis obliterans, chlorofluorocarbons, occupational irritant-induced asthma, reactive airways dysfunction syndrome, thermal degradation products.

Chlorofluorocarbons (CFC or freons) are still present in a variety of refrigeration appliances, although, according to an international agreement (Montreal Protocol) to protect stratospheric ozone, their manufacture will be essentially stopped in 2003. The most common CFC, used as refrigerants, aerosol propellants, and blowing agents for plastics, are trichlorofluoromethane [CFC-11, boiling point $25^{\circ} \mathrm{C}$ ], dichlorodifluoromethane (CFC-12, boiling point $-29.8^{\circ} \mathrm{C}$ ), some hydrogenated fluorocarbons, and 1,1,2-trichloro-1,2,2-trifluoroethane (CFC113 , boiling point $\left.47^{\circ} \mathrm{C}\right)(1,2)$. The last compound has also been used as a cleaning solvent. At low concentrations CFC are considered relatively harmless for human health, whereas, at high concentrations, they have caused several fatal accidents, mainly attributable to severe cardiac arrhythmias (3-5). In different work processes where the temperatures vary from 450 to $1000^{\circ} \mathrm{C}, \mathrm{CFC}$ decompose to produce, for example, carbonyl fluoride $\left(\mathrm{COF}_{2}\right)$, hydrogen fluoride (HF), chlorine $\left(\mathrm{Cl}_{2}\right)$, and hydrogen chloride $(\mathrm{HCl})(1,6)$, which are highly toxic, corrosive, and irritating in the airways and lungs. Most CFC are known to cause reactive airway dysfunction syndrome (RADS), defined as an asthmalike condition that develops without a latency period, following a single exposure to high levels of an irritant $(7,8)$.

1 Department of Occupational Medicine, Finnish Institute of Occupational Health, Helsinki, Finland.

2 Laboratory of Clinical Physiology, Helsinki University Hospital, Helsinki, Finland.

3 Department of Occupational Hygiene and Toxicology, Finnish Institute of Occupational Health, Helsinki, Finland.

Reprint requests to: Dr Päivi Piirilä, Helsinki University Hospital, Laboratory of Clinical Physiology, PO Box 360, 00029 HUS, Finland. [E-mail paivi.piirila@ hus.fi] 
Short-duration respiratory symptoms caused by heated CFC have been reported earlier $(9,10)$, and CFC are listed among chemicals causing $\operatorname{RADS}(11,12)$. However, the authors of the reports did not give the details of the cases, nor have we been able to find case reports of prolonged respiratory symptoms or RADS induced by CFC. One case of occupational asthma caused by CFC has been published (13); in this instance, the authors claimed that the mechanism was specific and nonirritant. In our report we present two incidents involving the irritant effects of heated CFC resulting in persistent respiratory symptoms among several exposed workers.

\section{Subjects and methods}

The primary lung function tests were conducted at a local health center for patient A1, whereas the other lung function studies were performed at the Finnish Institute of Occupational Health. Spirometry was carried out with a rolling-seal spirometer (Mijnhardt, Vicatest 3) connected to a microcomputer (Medicro MR-3) using Viljanen's reference values (14). The histamine challenge test was done according to the method of Sovijärvi et al (15), and the forced expiratory volume in 1 second $\left(\mathrm{FEV}_{1}\right)$ was followed with a Vitalograph $\mathrm{S}$ bellows spirometer (Vitalograph, Buckingham, England). The single breath diffusing capacity for carbon monoxide (DLCO) and the specific diffusing capacity (DLCO/VA) were measured with a Masterlab Transfer device (Erich Jaeger, Wurzburg, Germany) using Viljanen's reference values (14), and the steady state helium-dilution volume spirometry was carried out using the reference values of Grimby \& Söderholm (16). In the skin prick testing, 20 common environmental allergens were tested with a standard technique (17).

Bronchoscopy was done with a bronchofiberoscope (Olympus BF-XT30) after local anesthesia with 2\% lidocaine, and bronchoalveolar lavage (BAL) was performed and the fluid analyzed according to Taskinen et al (18) for patients B4 and B5 and according to Sutinen et al (19) for patient A1. The bronchial biopsies were immediately fixed in $10 \%$ neutral buffered formalin and subsequently processed using routine histological methods. Thin sections of the blocks were stained with a routine hematoxylin-eosin protocol.

Incident $A$. The patient (A1) involved in incident A, was a 53-year-old man who had been working as a refrigerator maintenance worker since the 1970s. He had smoked 10-20 cigarettes a day for 15 years. He had no atopy or chronic respiratory symptoms. At the time of the incident, he was brazing (20) a fractured copper pipe of a refrigerator with an acetylene oxygen torch (temperature range $450-870^{\circ} \mathrm{C}$ ). The leaking refrigeration fluid (the CFC was not specifically identified) flooded the work area. He continued working on the pipe for 1-2 hours without any breathing protection and felt dyspnea, cough, and pain in his chest. After the incident, he experienced dyspnea during exercise, during the night, and during cold weather. After 2 weeks he visited a municipal health center. The chest auscultation was normal, as was his chest X-ray. The C-reactive protein level was $<10 \mathrm{mg} / \mathrm{l}$, and the erythrocyte sedimentation rate was $2 \mathrm{~mm} / \mathrm{h}$. In a subsequent examination 8 months later, moderate bronchial hyperreactivity was found (table 1), and the spirometry showed slight obstruction (table 2) without response to a bronchodilator. In the clinical exercise test, slightly lowered exercise capacity was found, and an asthmatic reaction was suspected on the basis of pulmonary auscultation: wheezing sounds in forced expiration auscultated from the back on both sides. However, there was no reduction in the peak expiratory flow (PEF), nor was there any indication of coronary heart disease. In the diurnal peak flow monitoring, a variation of 550-630 1/min (10-20\%) was found. Inhaled fluticasone (1000 $\mu \mathrm{g} / \mathrm{day})$ was started and supplemented later with inhaled salmeterol (100 $\mu \mathrm{g} /$ day).

Two years later, as the respiratory symptoms still continued, he was remitted to the Finnish Institute of Occupational Health. He had stopped smoking after the accident and still used regular fluticasone and salmeterol inhalations. His chest X-ray was normal. In high-resolution computed tomography, no signs of emphysema or alveolitis were found. In spirometry, his forced vital capacity (FVC) was slightly reduced; however, his total lung capacity (TLC) was normal (table 2), showing that no volume restriction was present (16). His diffusing capacity was normal. No bronchial hyperreactivity was found in the histamine challenge test. Skin prick tests to 20 common allergens were negative. In the bronchoalveolar lavage fluid, the total cell count was slightly elevated, and a slight lymphocyte activation was observed (table 3 ). In bronchial biopsy, moderate hyperplasia of the epithelium and minor thickening of the basement membrane were found. The submucosa contained a moderate, predominantly mononuclear inflammatory infiltrate. The activity of the inflammation was higher than expected from smoking that had ceased 18 months earlier (figure 1).

Incident $B$. In a restaurant kitchen, the site of incident $\mathrm{B}$, a refrigerator maintenance worker disconnected the compressor piping of a refrigerator located above hot $\left(200-550^{\circ} \mathrm{C}\right)$ cooking plates. The action let CFC-12 leak into the premises without the personnel being informed. The workers heard a hissing sound in the compressor and noticed a peculiar smell. They experienced smarting pain in their eyes and throat and arrhythmias. They 
Table 1. Patients' data on smoking, atopy, lung function, and symptoms. (atopy = at least one positive reaction in skin prick testing with 20 common allergens, $A=$ patients in incident $A, B=$ patients in incident $B, P E F=$ peak expiratory flow, $P D_{15}=$ provocative dose of histamine disulfate causing a reduction of at least $15 \%$ in the forced expiratory volume in 1 second)

\begin{tabular}{|c|c|c|c|c|c|c|c|c|c|c|}
\hline Patient & Gender & $\begin{array}{l}\text { Age } \\
\text { (years) }\end{array}$ & Profession & $\begin{array}{l}\text { Smoking } \\
\text { (pack- } \\
\text { years) }\end{array}$ & Atopy & $\begin{array}{l}\text { Bronchial } \\
\text { hyperreactivity a }\end{array}$ & Spirometry & $\begin{array}{l}\text { PEF } \\
\text { variation }\end{array}$ & $\begin{array}{l}\text { Duration of } \\
\text { symptoms }\end{array}$ & Character of symptoms \\
\hline A 1 & Male & 49 & $\begin{array}{l}\text { Refrigerator } \\
\text { maintenance } \\
\text { worker }\end{array}$ & 11 & - & 0.27 & $\begin{array}{l}\text { Slight } \\
\text { obstruction }\end{array}$ & $10-20 \%$ & 4 years & Acute: dyspnea; late: dyspnea \\
\hline B1 & Male & 39 & Restaurant chef & - & - & $<1.6$ & Normal & $\begin{array}{l}\text { Not } \\
\text { studied }\end{array}$ & 1 day & $\begin{array}{l}\text { Acute: smarting in airways, } \\
\text { unwell feeling }\end{array}$ \\
\hline B 2 & Female & 57 & Kitchen maid & - & - & $<1.6$ & Normal & $\begin{array}{l}\text { Not } \\
\text { studied }\end{array}$ & 1 month & $\begin{array}{l}\text { Acute: unwell feeling, shortness } \\
\text { of breath; late: cough, produc- } \\
\text { tion of phlegm, weakness }\end{array}$ \\
\hline B3 & Female & 48 & Waitress & 12.5 & + & 0.74 & $\begin{array}{l}\text { Slight obs- } \\
\text { truction }\end{array}$ & $<10 \%$ & 12 months & $\begin{array}{l}\text { Acute: dyspnea; late: dyspnea } \\
\text { during exercise }\end{array}$ \\
\hline B 4 & Female & 36 & Cook & - & + & $\begin{array}{l}\text { Primarily } \\
<1.6, \\
4 \text { years later } \\
0.52\end{array}$ & Normal & $<10 \%$ & 4 years & $\begin{array}{l}\text { Acute: smarting of skin and } \\
\text { nose, palpitation and } \\
\text { arrhythmias, weakness and } \\
\text { fever; late: cough, production } \\
\text { of phlegm, dyspnea during } \\
\text { exercise }\end{array}$ \\
\hline B 5 & Female & 49 & Waitress & - & - & 1.3 & Normal & $<10 \%$ & 5 months & $\begin{array}{l}\text { Acute: eye irritation, nasal } \\
\text { symptoms, palpitation, } \\
\text { dyspnea; late: dyspnea, cough, } \\
\text { chest pain, tiredness }\end{array}$ \\
\hline B 6 & Female & 41 & $\begin{array}{l}\text { Restaurant } \\
\text { steward }\end{array}$ & 20 & - & $>1.6$ & Normal & $<20 \%$ & 5 years & $\begin{array}{l}\text { Acute: smarting of nose and } \\
\text { throat, arrhythmias, weakness, } \\
\text { dyspnea; late: dyspnea }\end{array}$ \\
\hline
\end{tabular}

a The hyperresponsiveness was graded as strong with $\mathrm{PD}_{15}<0.10 \mathrm{mg}$, moderate with $\mathrm{PD}_{15} 0.11-0.40 \mathrm{mg}$, and slight with $\mathrm{PD}_{15} 0.41-1.6 \mathrm{mg}$.

Table 2. Results of the spirometric examinations in the follow-up of patient A1. The incidence occurred in April 1996. (FVC = forced vital capacity, $\mathrm{FEV}_{1}=$ forced expiratory volume in 1 second, $\mathrm{MEF}_{50}=$ maximal expiratory flow at the volume level of $50 \%$ of the FVC, TLC = total lung capacity)

\begin{tabular}{|c|c|c|c|c|c|c|c|c|c|c|}
\hline \multirow{2}{*}{$\begin{array}{l}\text { Time of } \\
\text { examination }\end{array}$} & \multicolumn{2}{|r|}{ FVC } & \multicolumn{2}{|r|}{$\mathrm{FEV}_{1}$} & \multicolumn{2}{|c|}{$\mathrm{FEV}_{1} / \mathrm{FVC}$} & \multicolumn{2}{|c|}{$\mathrm{MEF}_{50}{ }^{\mathrm{a}}$} & \multicolumn{2}{|r|}{ TLC } \\
\hline & I & $\%$ of predicted & I & $\%$ of predicted & $\%$ & $\%$ of predicted & $1 / \mathrm{s}$ & $\%$ of predicted & I & $\%$ of predicted \\
\hline December 1996 & 4.66 & 97 & 3.31 & 85 & 71.1 & 88 & 2.90 & 57 & & \\
\hline March 1997 & 3.81 & 81 & 3.04 & 79 & 77.3 & 99 & 2.94 & 58 & 6.16 & $88^{a}$ \\
\hline February 1998 & 3.80 & 81 & 2.90 & 76 & 76.3 & 94 & 2.41 & 48 & & \\
\hline October 1998 & 3.62 & 77 & 3.02 & 79 & 83.5 & 103 & 3.56 & 70 & 5.74 & $85^{b}$ \\
\hline June 1999 & 3.33 & 72 & 3.0 & 79 & 90.0 & 111 & 4.46 & 89 & & \\
\hline
\end{tabular}

a Measured with the helium single breath method.

${ }^{\mathrm{b}}$ Measured with the helium multibreath method.

Table 3. Cytological findings in the bronchoalveolar lavage fluid of three patients. ( $C D=$ cluster designation, mill = million)

\begin{tabular}{|c|c|c|c|c|c|c|c|c|c|c|}
\hline Patient & $\begin{array}{l}\text { Time after } \\
\text { the exposure }\end{array}$ & $\begin{array}{l}\text { Total cell } \\
\text { count } \\
\text { (mill/l) }\end{array}$ & $\begin{array}{l}\text { Lymphocytes } \\
(\%)\end{array}$ & $\begin{array}{l}\text { Basophils } \\
(\%)\end{array}$ & $\begin{array}{l}\text { Eosinophils } \\
(\%)\end{array}$ & $\begin{array}{l}\text { Neutrophils } \\
(\%)\end{array}$ & $\begin{array}{l}\text { Macrophages } \\
(\%)\end{array}$ & $\begin{array}{l}\mathrm{CD}_{4}{ }^{\mathrm{a}} \\
\text { positive } \\
(\%)\end{array}$ & $\begin{array}{l}\mathrm{CD}_{8} \mathrm{~b} \\
\text { positive } \\
(\%)\end{array}$ & $\mathrm{CD}_{4} / \mathrm{CD}_{8}$ \\
\hline $\mathrm{A} / 1$ & $\begin{array}{l}2 \text { years \& } \\
8 \text { months }\end{array}$ & 194 & 26 & - & 2 & 2 & 70 & 37 & 57 & 0.6 \\
\hline $\mathrm{B} / 4$ & 5 weeks & 78 & 18 & - & 0.5 & 5.5 & 76 & 40 & 17 & 2.4 \\
\hline$B / 5$ & 5 weeks & 168 & 13 & 0.5 & 2 & 3.5 & 81 & . & . & . \\
\hline
\end{tabular}

a T-helper cells.

b T-cytotoxic cells.

went on working and tried to ventilate the room by opening windows. After 2 hours the repairman came back and found the system empty; altogether 500 grams of refrigeration fluid (100 liters of gas) had escaped. The sharp smell was possibly due to the thermal decompo- sition of CFC-12, which came in contact with the hot cooking plates.

All the attending six workers developed respiratory symptoms during the release of CFC-12 (table 1), and they were all examined at the Finnish Institute of 


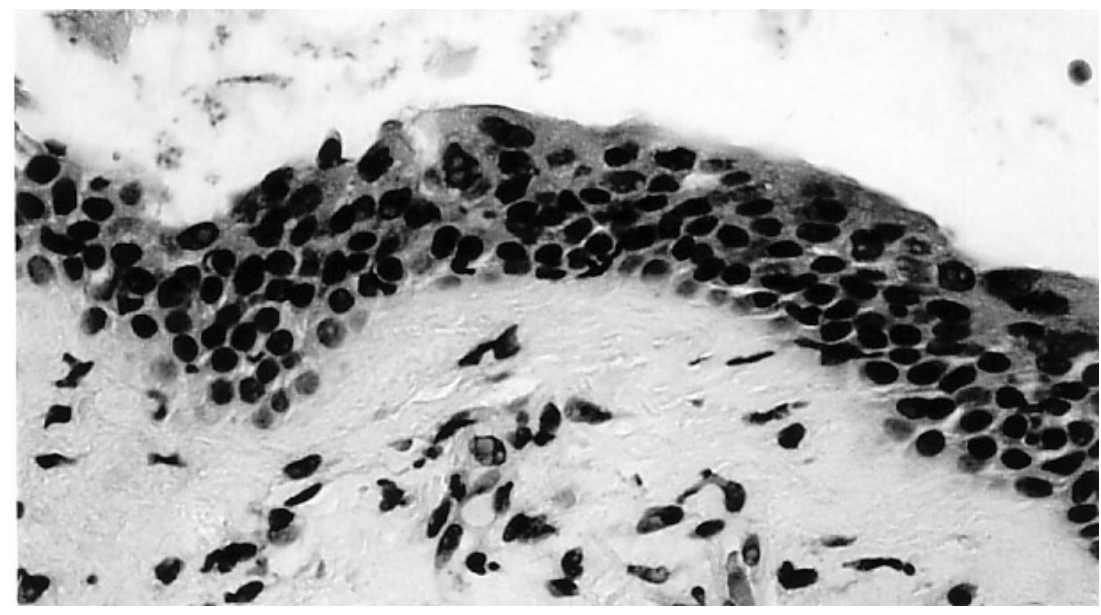

Figure 1. Histological specimen of bronchial biopsy from patient A1-showing hyperplasia of the epithelium, slightly thickened basement membrane, and mononuclear inflammatory infiltrate.

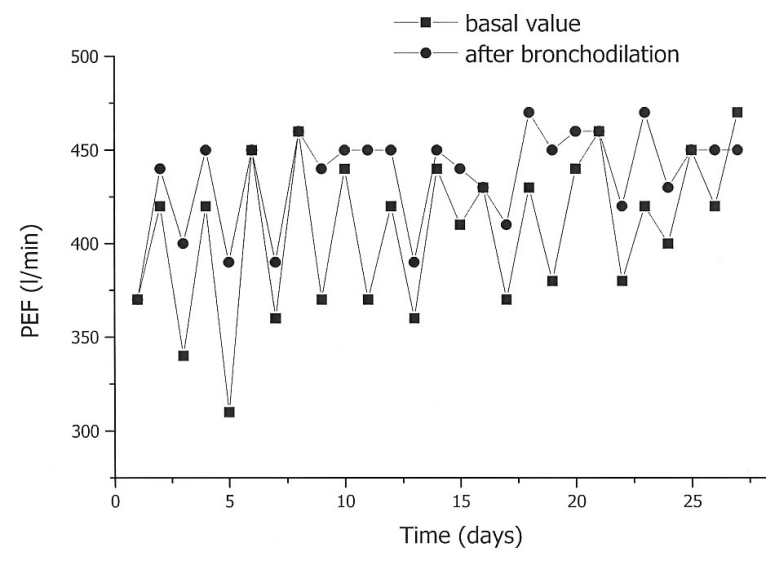

Figure 2. Peak flow monitoring (patient B6), showing more than $20 \%$ diurnal variation.

Occupational Health about 4 weeks later. The chest Xrays and diffusing capacity tests were normal for all of the patients. Patients B1 and B2 had normal lung function, and their symptoms that were compatible with irritant bronchitis disappeared within a month after the incident (table 1). Patient B3 had prolonged symptoms and bronchial hyperreactivity; however, her symptoms subsided after she stopped smoking and gave her cat away. Her symptoms may be explained by irritant-induced aggravation of underlying atopic symptoms.

Patient B4 had prolonged respiratory symptoms, and spirometry showed slight obstruction. In addition a slight neutrophilia was found in the bronchial lavage fluid (table 3 ). The histamine challenge test was negative, and the diurnal variation in the PEF was normal when studied 4 weeks after the incident. Inhaled steroids were started on suspicion of an irritative effect caused by the heated CFC. Four years later, the histamine challenge test showed slight bronchial hyperreactivity. In this patient's case, frequent respiratory infections could possibly explain the development of bronchial hyperreactivity.
Patient B5 experienced irritation of the eyes and dyspnea during the incident, and inhaled salbutamol was started on the next day. One month later, slight bronchial hyperreactivity was found; otherwise the lung function tests were normal. Viral antibodies were not elevated. In the bronchoalveolar lavage fluid, a slightly elevated cell count and slight neutrophilia were found (table 3). Inhaled beclomethasone (1500 mg/day) was started. Five months later, when the histamine challenge test was negative and the symptoms had subsided, the inhaled steroid was stopped.

Patient B6, the restaurant's steward, had smoked 1020 cigarettes a day for 28 years, but she claimed that she had not had respiratory symptoms earlier. After working the whole day at the scene of the incident she experienced mucosal and respiratory symptoms (table 1) strong enough to make her contact a local physician after the workday. She did not receive any treatment. Dyspnea, as well as smarting pain in the nasal and eye mucosa, continued. She also felt fatigue and had heart palpitation. She felt that her general condition had become worse and that her stress tolerance was lower. At the municipal health center, lung auscultation, electrocardiography, and a chest X-ray were normal. One month after the incident, spirometry, single breath diffusing capacity, and the histamine challenge test were normal. The clinical exercise test showed a normal physical condition without the pattern for exercise asthma. The skin prick tests to common allergens were negative. In the PEF follow-up, a variation of 310-480 1/min (25$36 \%$ ) and a bronchodilation effect of 20-25\% were found (figure 2). The patient refused bronchoscopy. After starting inhaled steroids (budesonide, $800 \mu \mathrm{g} /$ day) the PEF variation diminished. Attempts to lower the dose of inhaled steroids resulted in an increase in the PEF variation to $20-30 \%$. The symptoms and the need for inhaled steroids have now persisted for 5 years. 


\section{Discussion}

Our study, describing two incidents and seven persons with an acute onset of respiratory symptoms, shows that combustion products of CFC used in refrigeration systems may cause irritant effects in the airways. The respiratory symptoms were mild and of short duration in three patients, whereas the other four had respiratory symptoms and lung function abnormalities lasting from a couple of months to several years.

The effects of irritants depend on the intrinsic properties and concentration of the causative agents, and the emerging clinical pictures vary from an asthma-like condition to bronchiolitis obliterans (21). Strongly irritating compounds can be presumed among the combustion products of CFC. While there were no analytical data available concerning the thermal degradation of CFC, consideration of the thermal degradation products reported for fluoropolymers at similar temperatures (450$750^{\circ} \mathrm{C}$ ) (1), as used in brazing, provides the following hypotheses.

In incident $\mathrm{A}$, the refrigerant involved was not identified, however, a CFC compound (2) containing both chlorine and fluorine was likely at the time, and hence irritant breakdown products can be expected. On the basis of knowledge of the use of refrigerants in Finland over the past two decades, we cannot exclude the possible occurrence of a hydrogenated fluorocarbon (CHCF) in incident $\mathrm{A}$, and hence the liberation of aggressive hydrogen fluoride. The clinical picture of a bronchiolitis component in patient A1 may be explained by a more intense exposure due to the short distance to the source of toxic gases and the high pyrolysis temperature involved in brazing, but also (hypothetically) hydrogen fluoride exposure could have been a factor.

In incident $\mathrm{B}$, where the temperature of the cooking plates might have ranged from 200 to $550^{\circ} \mathrm{C}$, carbonyl fluoride and chlorine may have developed from CFC12 . Fluorine is chemically more tightly bound to the carbon of methane than chlorine atoms are, which leave the molecule already at $>200^{\circ} \mathrm{C}$ and form chlorine gas $\left(\mathrm{Cl}_{2}\right)$. Subsequent to chlorine liberation the methane carbon is subjected to an attack by oxygen, which yields carbonyl fluoride $\left(\mathrm{COF}_{2}\right)$ in a radical reaction $(1,2)$. In the CFC-12 molecule, there is no hydrogen for the generation of hydrogen chloride or hydrogen fluoride or fluorine-free carbon to yield phosgene. Chlorine can, however, react later with moisture in the air and form hydrogen chloride and hypochlorous acid.

Several case reports of irritant induced asthma or RADS caused by chlorine $(8,22-25)$ or hydrogen chloride $(10,26,27)$ have been published. Chlorine has also been known to cause bronchiolitis obliterans $(25,28)$. CFC used as refrigerants (11) and heated CFC (12) are mentioned as contributing factors to RADS, but more-detailed case descriptions or case reports are lacking. One case report of asthma claimed that heated CFC caused an asthmatic reaction by a specific nonirritant mechanism (13), although a commentary arguing in favor of an irritant mechanism was also published (10).

We argue that, in cases B 5-6 and A1, the data concerning the exposures, symptoms, and signs justify the diagnosis of acute irritant-induced asthma or RADS, case A1 having also a bronchiolitis component. Somewhat differing criteria for RADS have been presented earlier $(7,8,29,30)$. An agreement exists as regards the main criteria: absence of preceding respiratory complaints or other pulmonary disease, onset of asthma-like symptoms after an accidental inhalation of an irritant at a high concentration, and onset of asthma-like symptoms within 24 hours after exposure to an irritant. Some authors consider bronchial hyperreactivity as an obligatory finding (7). Others (30) suggest, as a main criterion, either hyperreactivity or reversible bronchial obstruction. Absence of previous symptoms should distinguish RADS from other diseases. On the basis of our clinical experience, we have adopted the criterion of either hyperreactivity or reversible obstruction or both by Alberts $\&$ do Pico (30). Moreover, we would prefer the term acute irritant-induced asthma to the acronym RADS. Accordingly, cases B5 and A1 fulfilled all the aforementioned criteria and displayed bronchial hyperreactivity, whereas case B6 exhibited only a reversible obstruction, as demonstrated by a PEF variation of over $20 \%$.

In our study, patients B6 and A1, with the most severe and long-lasting symptoms, were both smokers. Neither of them had respiratory symptoms before the accident. Similarly, Promisloff et al (27) reported that smokers exposed to hydrogen chloride developed RADS. According to Blanc et al (11) smoking may be a risk factor for the development of RADS.

The symptoms of patient A1, the refrigerator maintenance worker, began acutely, and the acuteness speaks rather for irritant-induced asthma than for asthma caused by allergic sensitization. There was no indication of a development of pulmonary edema, but symptoms suggesting obstructive ventilatory impairment started immediately. Lung function data were not, however, available from the acute phase. After 8 months, slight obstruction and moderate bronchial hyperreactivity were found. Two years later, the bronchial hyperreactivity had disappeared, and the spirometric results indicated dynamic restriction with normal total lung capacity. This result could represent the end-stage of an inflammatory process or a bronchiolitis type disease $(28,31)$. Peripheral obstruction, reduced $\mathrm{FEV}_{1}$, and normal diffusion capacity have been described as characteristic of bronchiolitis obliterans (32). Development of a restrictive lung function pattern after exposure to an irritant has been described in several reports $(21,33-36)$; in some 
cases a similar pattern of reduced FVC and normal or high total lung capacity has been reported $(35,37)$. Absence of bronchial hyperreactivity in the later phase may depend on the steroid medication used or smoking cessation after the incident. However, it may also suggest the location of the lesion to be the small airways, corresponding to bronchiolitis obliterans; the presence of bronchial hyperreactivity probably needs involvement of the larger airways (38). The clinical picture of the present patient was not so severe that a lung biopsy would have been indicated.

Unfortunately, there were no bronchial biopsy specimens from the acute phase. For patients B4 and B5, neutrophilia in the bronchoalveolar lavage fluid could have indicated an irritant reaction in the lungs. For patient A1, bronchial biopsies and broncoalveolar lavage were performed more than 2 years after the exposure. The predominantly lymphocytic inflammation found in the biopsy was in accordance with earlier observations of chronic RADS $(7,8)$. In addition, the lymphocytosis found in the bronchoalveolar lavage fluid was consistent with the findings of Gautrin et al (39) in the chronic stage of RADS.

Our report suggests that thermal degradation products of CFC may cause long-lasting respiratory symptoms through toxic or irritant mechanisms rather than through hypersensitivity mechanisms. The clinical pictures varied from mild bronchitis without functional impairment to acute irritant-induced asthma or RADS. Although CFC compounds are being phased out, they may still occur extensively in old refrigeration systems, and incidents similar to the ones described in this report are possible. To safeguard maintenance workers, as well as bystanders, from hazardous exposure, good work practices are needed.

\section{Acknowledgments}

Our thanks go to Terttu Kaustia for revising the language of the manuscript.

\section{References}

1. Harris LR, Sarvadi DG. Synthetic polymers: fluoropolymers. In: Clayton, GD, Clayton FE, editors. Pattys's industrial hygiene and toxicology; vol II, part E (Toxicology). 4th ed. New York (NY): John Wiley \& Sons, Inc; 1994. p 3778-95.

2. Aviado DM, Micozzi MS. Fluorine-containing organic compounds. In: Clayton GD, Clayton FE, editors. Pattys's industrial hygiene and toxicology; vol 2B (Toxicology). 3rd ed. New York (NY): John Wiley \& Sons, Inc; 1981. p 3071-115.

3. McGee MB, Meyer RF, Jejurikar SG. A death resulting from thrichlorotrifluoroethane poisoning. J Forensic Sci 1990;35 (6):1453-60.

4. Groppi A, Polettini A, Lunetta Ph, Achille G, Montagna M. A fatal case of trochlorofluoromethane (Freon 11) poisoning: tissue distribution study by gas chromatography-mass spectrometry. J Forensic Sci 1994;39(3):871-6.

5. Poklis A. Determination of fluorocarbon 11 and fluorocarbon 12 in postmortem tissues: a case report. Forensic Sci 1975;5:53-9.

6. Shusterman DJ. Polymer fume fever and other fluorocarbon pyrolysis-related syndromes. Occup Med 1993;8:519-31.

7. Brooks SM, Weiss MA. Reactive airways dysfunction syndrome (RADS): persistent asthma sydromes after high level irritant exposures. Chest 1985;88:376-84.

8. Gautrin D, Bernstein IL, Brooks S. Reactive airways dysfunction sydrome or irritant induced asthma. In: Bernstein IL, Chan Young M, Malo J-L, Benrstein DI, editors. Asthma in the workplace. New York, Basel: Marcel Dekker Inc; 1999. p 565-93.

9. Wyatt JP, Allister A. Occupational phosgene poisoning: a case report and review. J Accid Emerg Med 1995;12:212-3.

10. Field GB. Occupational asthma due to heated freon. Thorax 1985;40(4):320.

11. Blanc PD, Galbo M, Hiatt P, Olson KR, Balmes JR. Symptoms, lung function and airway responsiveness following irritant inhalation. Chest 1993;103(6):1699-705.

12. Brooks SM, Hammad Y, Richards I, Giovinco-Barbas J, Jenkins K. The spectrum of irritant-induced asthma: sudden and not-so-sudden onset and the role of allergy. Chest 1998; 113:42-9.

13. Malo JL, Gagnon G, Cartier A. Occupational asthma due to heated freon. Thorax 1984;39:628-29.

14. Viljanen AA, editor. Reference values for spirometric, pulmonary diffusing capacity and boly plethysmographic studies. Scand J Clin Invest 1982;42 Suppl 159:1-50.

15. Sovijärvi ARA, Malmberg LP, Reinikainen K, Rytilä P, Poppius $H$. A rapid dosimetric method with controlled tidal breathing for histamine challenge: repeatability and distribution of bronchial reactivity in a clinical material. Chest 1993;104:164-70.

16. Grimby G, Söderholm B. Spirometric studies in normal subjects. Acta Med Scand 1963;173:199-206.

17. Kanerva L, Estlander T, Jolanki T. Skin testing for immediate hypersensitivity in occupational allergology. In: Menne T, Maibach HI, editors. Exogenous dermatoses: environmental dermatitis. Boca Raton (FL): CRC Press; 1991. p 103-26.

18. Taskinen E, Tukiainen P, Renkonen . Bronchoalveolar lavage: influence of cytologic techniques on the cellular picture. Acta Cytol 1992;36:680.

19. Sutinen S, Riska H, Backman R, Sutinen SH, Fröseth B. Alveolar lavage fluid (ALF) of normal volunteer subjects: cytologic, immunocytochemical, and biochemical reference values. Respir Med 1995;89:85-92.

20. Krappiz H. Soldering and brazing. In: Elvers B, Hawkins S, Russey W, Schulz G, editors. Ullmann's encyclopedia of industrial chemistry. Weinheim: VCH Verlagsgesellschaft; 1993. p 427-36.

21. De la Hoz, Schlueter DP, Rom WN. Chronic lung disease secondary to ammonia inhalation injury: a report on three cases. Am J Ind Med 1996;29:209-14.

22. Tarlo S, Broder IB. Irritant-induced occupational asthma. Chest 1989;96:297-300.

23. Lemiere C, Malo J-L, Boutet M. Reactive airways dysfunction syndrome due to chlorine: Eur Respir J 1997;10:241-4.

24. Schwartz DA, Smith DD, Lakshiminarayan S. The pulmonary sequelae associated with accidental inhalation of chlorine gas. Chest 1990;97:820-5.

25. Kowitz TA, Reba RC, Parker RT, Spicer WS. Effects of 
chlorine gas upon respiratory function. Arch Environ health 1967;14:545-58.

26. Boulet LP. Increases in airway responsiveness following acute exposure to respiratory irritants. Chest 1988;94:476-81.

27. Promisloff RA, Lenchner GS, Cichelli AV. Reactive dysfunction syndrome in three police officers following a roadside chemical spill. Chest 1990;98:928-9.

28. King TE. Bronchiolitis obliterans. Lung 1989;167:69-93.

29. Chan-Yeung M. Assessment of asthma in the workplace. Chest 1995;108:1084-117.

30. Alberts WM, do Pico GA. Reactive airways dysfunction syndrome. Chest 1996;109:1618-26.

31. Weiss SM, Lakshminarayan S. Acute inhalation injury. Clin Chest Med 1994;15:103-16.

32. Epler GR. The clinician's classification of the diseases of the bronchioles. In: Epler GR, editor. Diseases of the bronchioles. New York (NY): Raven Press Ltd; 1994. p 101-12.

33. Gilbert R, Auchincloss J. Reactive airways dysfunction sydrome presenting as a reversible restrictive defect. Lung 1989;167:55-61.

34. Chan-Young M, Lam S, Kennedy S, Frew AJ. Persistent asthma after repeated exposure to high concentrations of gases in pulp mills. Am J Respir Crit Care Med 1994;149: 1676-80.

35. Ward K, Murray B. Acute and long-term pulmonary sequelae of acute ammonia inhalation. Ir Med J 1983;76:279-81

36. Woodford DM, Coutu RE, Gaensler DA. Obstructive lung diesease from acute sulfur dioxide exposure. Respiration 1979;38:238-45.

37. Piirilä PL, Nordman H, Korhonen OS, Winblad I. A thirteenyear follow-up of respiratory effects of acute exposure to sulfur dioxide. Scand J Work Environ Health 1996;22:1916.

38. Ruffin RE, Dolovich MG, Wolff RK, Newhouse MT. The effects of preferential deposition of histamine in the human airway. Am Rev Respir Dis 1978;117:485-92.

39. Gautrin D, Boulet L-P, Boutet M, Dugas M, Bherer L, L'Archeveque J, et al. Is reactive airways dysfunction syndrome a variant of occupational asthma? J Allergy Clin Immunol 1994;93:12-22.

Received for publication: 17 July 2002 